\title{
Comparative Area Studies: \\ Epistemological and Methodological Foundations and a Practical Application ${ }^{1}$
}

\author{
D. Berg-Schlosser \\ Philipps-Universität Marburg, Marburg, Germany
}

\begin{abstract}
In recent decades, area studies have been transformed from mostly descriptive ethnographic and historical accounts to theory-oriented and analytical approaches. They retain some of their depth and cultural specificity, but have been widened in a comparative sense to come up with some broader social scientific explanations. This has been enhanced by more recent systematic comparative methods such as "Qualitative Comparative Analysis" (QCA) and related procedures, which are particularly suitable for medium- $\mathrm{N}$ studies of specific regions at the macro-level and cross-area analyses in contrast to more common statistical approaches. This paper discusses the epistemological background of this approach as well as recent methodological developments. As an illustration, it provides an example of an ongoing large international "cross-area" research project concerned with successful democratic transformations in different world regions and more recent threats to democratic stability and some of their underlying causes. Here, in particular, the relationships between level of socio-economic development and liberal democracy (the "Lipset hypothesis") and the effects of "good governance" in terms of the World Bank indicators on democratic stability are investigated. This is done on the basis of selected "cross-area" cases with the help of both crisp-set and fuzzy-set QCA. In this way, both the utility of this approach for "medium-range theorizing" in the social sciences and possible practical-political applications are demonstrated.
\end{abstract}

Key words: cross-area studies, social science epistemology, Qualitative Comparative Analysis (QCA), empirical democratic theory, liberal democracy under threat

For citation: Berg-Schlosser, D. (2020). Comparative Area Studies Epistemological and Methodological Foundations and a Practical Application. Vestnik RUDN. International Relations, 20 (2), 288-302. DOI: $10.22363 / 2313-0660-2020-20-2-288-302$

Научная статья

\section{Сравнительное регионоведение: эпистемологические и методологические основы и практическое применение}

\author{
Д. Берг-Шлессер \\ Марбургский университет им. Филиппа, Марбург, Германия
}

\begin{abstract}
В последние десятилетия региональные исследования трансформировались из описательных этнографических и исторических эссе в теоретически ориентированные и аналитические работы. Они сохраняют глубину и культурную специфику, но в сравнительном плане были расширены и теперь представляют собой более комплексные объяснения в рамках общественной науки. Данный инструментарий был усилен современными сравнительными методами, такими как качественный сравнительный анализ (QCA), и смежными процедурами, которые
\end{abstract}

${ }^{1}$ The first part of this article is a revised and updated version of the chapter in [Ahram, Köllner, Sil 2018].

(C) Berg-Schlosser D., 2020 
(в отличие от более распространенных статистических подходов) применяются для исследований средних по размеру N-выборок в рамках конкретных регионов на макроуровне и трансрегиональных исследований. В статье обсуждаются эпистемологические основы данного подхода, а также показаны последние методологические разработки в его рамках. В качестве иллюстрации приводится пример продолжающегося крупного международного исследовательского проекта, связанного с успешными демократическими преобразованиями в различных регионах мира, угрозами демократической стабильности и их основными причинами. В частности, исследуется взаимосвязь между уровнем социально-экономического развития и либеральной демократией («гипотеза Липсета») и влиянием эффективного управления (в оценке Всемирного банка) на демократическую стабильность. Анализ проводится на основе отдельных трансрегиональных кейсов с помощью инструментария качественных региональных исследований, в том числе теории нечетких множеств. Кейс демонстрирует полезность данного подхода для создания теорий среднего уровня, а также его значение для прикладной политической экспертизы.

Ключевые слова: трансрегиональные исследования, социальная эпистемология, качественный сравнительный анализ (QCA), эмпирическая демократическая теория, либеральная демократия

Для цитирования: Berg-Schlosser D. Comparative Area Studies: Epistemological and Methodological Foundations and a Practical Application // Вестник Российского университета дружбы народов. Серия: Международные отношения. 2020. Т. 20. № 2. С. 288-302. DOI: 10.22363/2313-0660-2020-20-2-288-302

\section{Introduction}

Area studies have undergone significant changes over the last two decades. They have been transformed from mostly descriptive accounts in the international context of the Cold War to theory-oriented and analytical approaches. More recent comparative methods such as "Qualitative Comparative Analysis" (QCA) and related procedures, which are particularly suitable for case-sensitive small and medium $\mathrm{N}$ studies, have significantly contributed to this development. Deeper knowledge of regional and cultural features and their historical roots and developments has not lost any of its significance. Thus, research on "political culture" experienced a renaissance in various ways and with different aims [Huntington 1996; Inglehart 1997; 2018].

The apprehension of different civilizations, broad cultural regions and their conflicts and interactions gained a new significance. Many viewed such ideas to be confirmed by the events of September 11, 2001. Along this vein, regional factors and neighborhood effects were of central significance not just for the differing paths taken by countries in the waves of democratization such as more recently in the "Arab Spring" but also for international politics [Katzenstein 2005; Berg-Schlosser 2008a]. The rationalchoice theorists also increasingly ascribed more value to a context-dependent "bounded rationality" (a term originally coined by Herbert Simon [1957], corresponding "analytic narratives" [Bates, Greif, Levi, Rosenthal, Weingast 1998] and multi-method approaches [Laitin 2007].
In the meantime, comparative methodology has also made considerable advancements; "deep" single-case studies and "thick descriptions" in the tradition of ethnographic and social anthropological approaches [Geertz 1973], on the one hand, are no longer juxtaposed to large-N purely quantitative analyses on the other. The comparative method in the narrower sense of systematic comparisons of relatively few cases in the tradition of John Stuart Mill underwent important developments [Ragin 1987; Rihoux, Ragin 2009]. This progress was also beneficial to area studies, which necessarily have to work with a small or medium " $N$ " (for example the 19 countries of Latin America, or the 27 current member states of the European Union). Therefore, a reassessment of the state of area studies and any further advancements is called for [Almond 2002: 109-127; Szanton 2002; Basedau, Köllner 2007; Ahram 2009].

In what follows, I will start by providing a brief background based on a general philosophy of science and specific epistemological conditions for the social sciences. From there, I will elaborate newer comparative methods and the "comparative area studies" or "cross-area studies" approach, which attempts to gain social scientific insights from research across two or several world regions broadly defined by particular cultural and historical conditions. In the words of the editors of a recent book on this subject: "Comparative Area Studies (CAS) refers to a broad approach consisting of any selfconscious effort to do two things simultaneously: 
(i) balance deep sensitivity to context in each of the locales being examined with the use of some variant of the comparative method to surface causal linkages that are portable across world regions; and (ii) engage ongoing research and scholarly discourse in two or more area studies communities against the backdrop of more general concepts and theoretical debate within a social science discipline" [Ahram, Köllner, Sil 2018: 1] (italics in the original. - Author's Note).

Subsequently, I will provide an example from ongoing recent research. I conclude by a short discussion of the field's further perspectives. Given my own background, this will be undertaken primarily from a contemporary political science and comparative politics point of view, though the contributions of other disciplines and of International Relations in particular, certainly should not be denied.

\section{Epistemological Background}

The current debates are in many ways linked to long-standing controversies in the philosophy of science, including the differentiation between idiographic (single-case) and nomothetic (lawseeking) approaches [Windelband 1912]; inductive vs. deductive methodologies [Popper 1969]; the putative existence of "covering laws" [Hempel 1952]; and, finally, the more general questions of whether social science can claim to be value-neutral [Weber 1922] and the role and responsibility of scholars. Of course, all of these issues can be alluded to only very briefly here [Badie, Berg-Schlosser, Morlino 2011: li-lxvii]. It is, however, necessary to put this discussion in its proper context.

Broadly speaking, we can highlight three crucial differences between the natural sciences and the social sciences that have strongly informed the epistemological debates. One aspect relates to the multidimensionality of the subject matter of the social sciences. In contrast to the natural sciences, the social sciences deal with not only "objective" conditions but also subjective perceptions and behaviors of individual people and groups. These also correspond to certain "normative" yardsticks in each culture. This three-dimensionality is, for all intents and purposes, beyond dispute; however, opinions are split not only on how to analytically differentiate these dimensions, but also on the question of whether an individual scholar can take a "holistic" [Hegel 1833/1956; Lukács 1967] or a "value-neutral" position [Weber 1922]. This cannot be further elaborated here, but suffice it to say that comparative political science has an unequivocal empirical-analytical focus, at the fore of which are "object" and "subject" dimensions, although normative questions - such as those in the context of democracy and general human rights - are often unavoidable. Every social scientist is, of course, also a human being and a citizen of a particular country and, for this reason, must substantiate one's judgments and acknowledge personal accountability.

A second fundamental difference between the natural and social sciences relates to the permanency or mutability of the subject matter in question. Karl Popper [1993: 214-267] speaks in this context of a continuum between "clocks" (highly deterministic sequences) on the one end and "clouds" (very diffuse, nebulous constructs) on the other. In this regard, the social sciences occupy a middle position of a "plastic" and malleable subject matter that changes in the course of time. This subject matter nevertheless exhibits certain recognizable structures and patterns and allows for certain more general observations in the context of "middle-range theories" [Merton 1949] restricted in space and time. Almond and Genco [1977] took this up and elaborated the consequences for comparative political science. In this way, the concrete regional and historical dimensions of area studies are shaped and may lead to certain "morphothetic" (clearly recognizable patterns and sequences) insights rather than general "laws".

The third difference relates to the notion that social scientists themselves are always, in one form or another, a part of the subject matter in question and thus are, whether purposely or not, self-referential [Luhmann 1990]. On the one hand, this causes particular epistemological problems relating to the intersubjective verification of one's findings by other social 
scientists. On the other hand, it provides an opportunity to tap into the thoughts and behavior of others through introspection and "Verstehen" (M. Weber). In this way, participatory observation, "grounded theory," and other similar methods open up new paths of access precisely in the area of intercultural comparison; these pathways, however, must always be further verified and validated by others. Furthermore, the possibility of self-fulfilling or self-defeating prophecies - such as in the case of forecasts of elections, stock prices or currency rates, if these are pronounced with some authority - indicates self-referential relationships.

Finally, it is important to keep in mind the more general social scientific explanatory model of "Coleman's Bathtub," which clarifies the relationships between the micro-, meso-, and macro-levels of social scientific analysis (see Fig. 1).

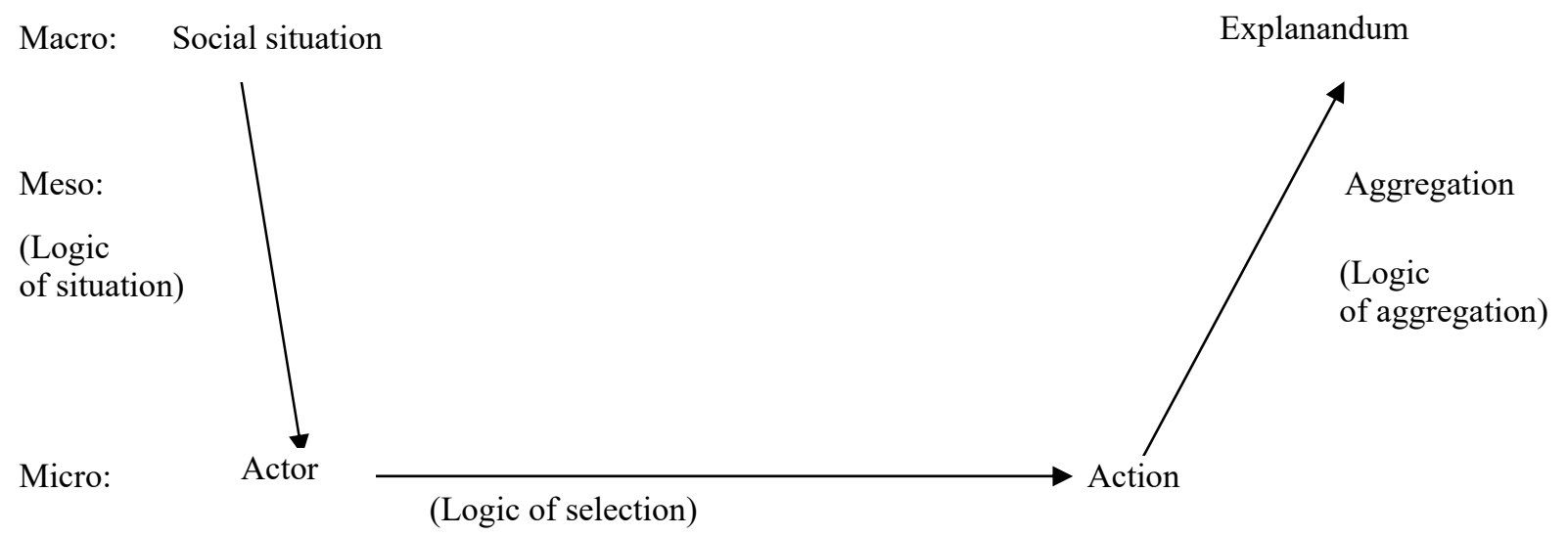

Fig. 1. Levels of Analysis according to Coleman [1990] and Esser [1993] Source: Adapted from [Coleman 1990: 8; Esser 1993: 98].

The starting point here is the concrete (historical, regional, cultural, etc.,) social context on the macro level (on the top left), which also includes the "objective" conditions of occurrence and the range of possible courses of action ("opportunity set") [Elster 1989]. These are perceived "subjectively" on the micro-level by individual persons and actors (bottom left) and translated into concrete actions or lack thereof (bottom right). These individual actions can then be organized and aggregated in various forms (interest groups, associations, social movements, political parties, etc.) on the meso-level (middle right) in order to ultimately leading to an explanation (e.g. of concrete decisions in the political system) on the macro-level (top right).

Separating these levels and comprehending their interdependence helps to avoid potential logical fallacies or unclear (and often unsubstantiated) assumptions. From an orthodox Marxist perspective, for example, the "objective" conflicts of the social structure on the macrolevel (top left) are connected directly to the expected political (e.g. revolutionary) consequences (top right), without adequately taking into account the level of consciousness on the micro-level, possible aggregation problems on the meso-level, and so on. In a similar way, this applies to the assumption - as by classical and neoclassical political economy or rational-choice theory - of a maximization of utility solely in terms of material needs on the part of individuals on the micro-level which does not appropriately take into account the macro-level cultural or similar context (top left) or the (often quite serious) aggregation problems on the meso-level (middle right).

In my view it is important to continuously keep in mind such epistemological considerations and limitations when examining other cultures and regions. The "social construction" of reality [Berger, Luckmann 1969] in this sense must always be taken into account. Nevertheless, gaining more general insights in the social sciences (though limited in time and space) is both achievable and desirable. Systematic- 
comparative methods independent of the respective meta-theoretical and ontological underlying assumptions are of crucial importance in that process [Moses, Knutsen 2012].

\section{Recent Comparative Methods}

Since J.S. Mill's A System of Logic [Mill 1843/1974], the limitations of both the comparative procedures that he delineated (among others, the "method of agreement" and the "method of difference") and the opportunity to conduct "quasi-experiments" have been pointed out frequently in the social sciences. Even Mill himself was keenly aware of this. Nevertheless, Mill's ideas can be applied in the investigation of the "conditions of occurrence" (at the macro-level at the top left of the Fig. 1) [Cohen, Nagel 1934]. Przeworski and Teune's [1970] seminal work highlighted the significance of comparisons made by "most similar" and "most different" systems designs. But for a long time, the analysis of actual similarities and differences on the macro-level of political

MDSO

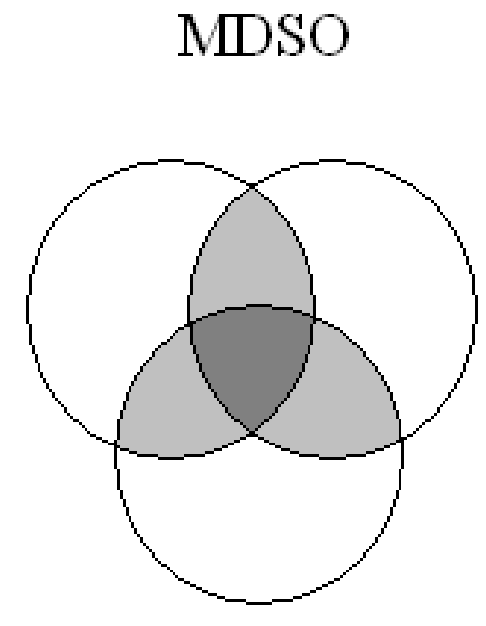

systems was not systematically operationalized [Przeworski 1987]. Instead, at best certain approximations in the investigation of particular regions or sub-regions predominated - for example concerning the (in some respects) relatively similar Scandinavian states, the countries of the Maghreb, or the East African states.

The characteristic problem of such studies, dealing with a small number of very complex cases (the "small N - many variables dilemma" [Lijphart 1971; 1975]), could not be surmounted. In that respect, De Meur and Berg-Schlosser [1994; 1996] were the first to present a more comprehensive, but also relatively elaborate, operationalization of the systematic measurement of similarities and differences of complex systems with regard to the respective research question ("outcome"), whereby "most similar systems with different outcomes" and "most different systems with similar outcomes" designs (MSDO and MDSO) can control for important influencing factors and direct the focus on the remaining areas (see Fig. 2).

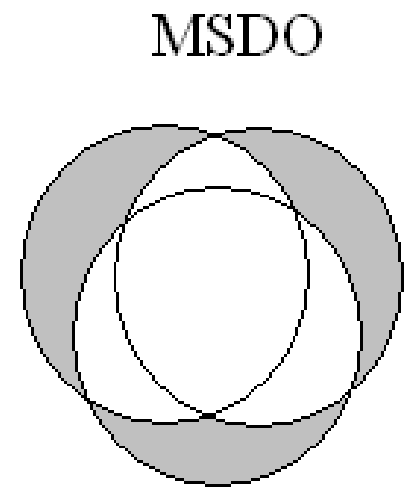

Fig. 2. "Most similar systems with different outcomes" (MDSO) and "Most different systems with similar outcomes" (MSDO) Designs Source: [Berg-Schlosser 2012: 36].

Showing paired and three-way comparisons, the shaded areas here reflect the potentially significant factors for the outcomes, while the white areas can be disregarded and are "controlled for".

In a parallel development, above all Charles Ragin [1987; 2000; 2008] concentrated on systematic comparisons in small-N and medium$\mathrm{N}$ situations (Qualitative Comparative Analysis, QCA), along with the procedures derived from it based on Boolean algebra and set theory. Initially, these were based exclusively on the use of dichotomized variables (values of 0 or 1 ) as in the digital appliances of electrical engineering 
from which the original algorithms were borrowed. These methods have since been put to diverse uses, even beyond realms covered by comparative political science and sociology ${ }^{1}$. A crucial aspect of this approach is the potential to reduce complexity through systematic and stepby-step paired comparisons that ultimately lead to the determination of the remaining relevant factors ("prime implicants") — to some extent also in various combinations ("conjunctural causation" or "equifinality"). The central rule can be summarized as follows: "If two Boolean expressions differ in only one causal condition yet produce the same outcome, then the causal condition that distinguishes the two expressions can be considered irrelevant and can be removed to create a simpler, combined expression" [Ragin 1987: 93].

This is demonstrated in the following example:

$$
A^{*} B^{*} C+A^{*} B^{*} c=\mathrm{O},
$$

meaning one or (+ represents a Boolean "or") the other combination leads to the same outcome. This can be reduced to $A^{*} B=O$, whereby the presence or absence of $C$ (expressed in upper- or lowercase, respectively) can be considered irrelevant.

Since its inception, this method and the corresponding software have been advanced for use with multi-value variables (mv-QCA) and "fuzzy sets" (fs-QCA) [Rihoux, Ragin 2009]. These methods represent an area that is important in and of itself, particularly for analyses with a relatively small number of cases, in contrast to macro-quantitative statistical methods, which necessitate as large a number of cases as possible and usually random sampling [Aarebrot, Bakka 2006; Niedermayer, Widmaier 2006]. They lend themselves particularly for use in area studies and cross-area studies. Because all of these methods are based on the foundations of set theory rather than statistical principles, the overarching term "configurational methods" has been adopted. Table 1 depicts the prevailing procedures given different numbers of cases.

1 Comparative Methods for Systematic Cross-Case Analysis. URL: http://www.compasss.org/ (accessed: 27.04.2020).
Usage of Configurational Comparative Methods

\begin{tabular}{|c|c|c|c|}
\hline $\begin{array}{c}\text { Number } \\
\text { of cases }\end{array}$ & $\begin{array}{c}\text { Small N } \\
(\sim 2-5 \text { cases })\end{array}$ & $\begin{array}{c}\text { Medium N } \\
(6-25 \text { cases })\end{array}$ & $\begin{array}{c}\text { Larger N } \\
(>25 \text { cases })\end{array}$ \\
\hline $\begin{array}{c}\text { Many } \\
\text { variables }\end{array}$ & MSDO & $\begin{array}{c}\text { MDSO, } \\
\text { QCA, } \\
\text { mv-QCA }\end{array}$ & $\begin{array}{c}\text { fuzzy sets, } \\
\text { fs-QCA }\end{array}$ \\
\hline
\end{tabular}

Source: [Berg-Schlosser 2012: 37].

As shown, depending on the number of cases, certain procedures are most appropriate. If there is a very small number of cases within a region or sub-region, MSDO may be best; for a region with more cases, MDSO, QCA and mv-QCA make more sense. Given a larger number of cases, fs-QCA is more useful. Crossarea studies (see below) generally work on the basis of specifically selected cases that generally lie in the small-N or medium-N range. However, these numbers denote only the respective focal points; the transitional areas are fluid.

The substantial differences between configurational and statistical methods are compiled in Table 2. The yield of statistical studies on a regional level - generally low in the past - is due to the number of cases being too small to undertake more discerning procedures (different from, for example, survey research with a large number of respondents). Random sampling is not possible; and only general conclusions spanning all cases can be reached. Hence, at least complementarily, both types of methods in intra- and inter-area studies should be utilized [Berg-Schlosser, Quenter 1996; Berg-Schlosser 2008b].

\section{Comparative Area Studies - A Practical Application from Current Research}

At this point, we must first make a terminological distinction. Area studies can be applied to one region and, where applicable, detect differentiations within it ("intra-area studies"). In the past this was overwhelmingly the case. Area studies can also perform comparisons between entire regions, either by comparing characteristics as independent analytical units (such as the degree of regional cooperation within the EU as compared to ASEAN) or by introducing "region" as a dummy 
variable within a broader macro-quantitative scope in order to determine statistically significant differences ("inter-area studies") [Berg-Schlosser 1985; 1990]. A third variant of area studies relates to selected cases across many regions ("cross-area studies") in order, for example, to determine any shared political characteristics of oil-producing states [Basedau, Köllner 2007]. I would like to elaborate here a little further on this last variant of regional studies, which has found itself less at the forefront, but which opens up new possibilities.

\section{Central Differences of Macro-qualitative and Macro-quantitative Methods}

\begin{tabular}{|l|l|l|}
\hline \multicolumn{1}{|c|}{ Features } & \multicolumn{1}{c|}{ Macro-qualitative (configurational) } & \multicolumn{1}{c|}{ Macro-quantitative (statistical) } \\
\hline Cases & Known & More or less anonymous \\
\hline $\mathrm{N}$ & Small to medium & Large \\
\hline Selection & $\begin{array}{l}\text { Goal-oriented (e.g. MSDO/MDSO } \\
\text { designs), each case relevant }\end{array}$ & $\begin{array}{l}\text { As many as possible, preferably randomized, } \\
\text { "outliers" often ignored }\end{array}$ \\
\hline Complexity & High & Low \\
\hline Causal model & $\begin{array}{l}\text { Necessary and sufficient conditions, } \\
\text { possibly "conjunctural", "equifinality" }\end{array}$ & $\begin{array}{l}\text { Correlations, regressions, mean values across } \\
\text { all cases } \\
\text { "Thin", probabilistic }\end{array}$ \\
\hline Explanation & "Thick", deterministic & "Theneralizable) \\
\hline Validity & "Internal" (only observed cases) & "External" (inferential, general \\
\hline Coverage & Limited & Potentially universal \\
\hline Range of the theory & Medium & Large \\
\hline Methods & Systematic-comparative, e.g. QCA & Statistical \\
\hline
\end{tabular}

Source: designed by the author.

But first of all we must acknowledge that even the term "region/area" is somewhat fuzzy and can refer to fluid transitional zones. While Huntington [1996] described eight or nine most important civilizations (he was not all that sure himself), Inglehart [1997] finds eight main regional cultural clusters. In many instances, only broad differentiations are made: (SubSaharan) Africa, Latin America (and the Caribbean), the Middle East and North Africa (MENA), and Asia. We might add to that list the former Soviet (CIS) and post-communist states. The OECD states are generally excluded and not viewed from a regional perspective. In addition, (Western) Europe and the former British settler colonies (the United States, Canada, Australia, and New Zealand) are sometimes designated separately.

As this list demonstrates, the way regions are delimited is characterized by a mixture of geographical, geopolitical, religious-cultural, and historical (e.g. a shared colonial past) factors. The organizational arrangement of research institutes that cover these areas varies accordingly [Badie, Berg-Schlosser, Morlino 2011: 86-89]. Nevertheless, even an imprecise classification that features certain fluidity has its uses, and the commonalities within each given region can be empirically substantiated as independent influencing factors [Ahram 2009]. Cross-regional cooperation, as used in cross-area studies, is therefore all the more important. Ultimately decisive for regional classification and case selection is the respective theory-driven research question, as will be demonstrated below by an example from an ongoing research project in which I collaborate.

The original "Transformation Research Initiative" (TRI) project [Van Beek 2005] covered at first five and later seven cases based on three criteria:

— regional diversity of recent "third wave" democracies;

- variety of authoritarian legacies;

- relatively successful democratic transitions in the respective regions.

For these reasons, we selected Chile, Poland, South Africa, South Korea and Turkey. Two "benchmark" cases of consolidated democracies, Germany (with its mixed EastWest background) and Sweden, were also included. This was thus a "Most Different 
Systems Similar Outcomes" (MDSO) cross-area research design.

For an ongoing project at the "Transformation Research Unit" (TRU) at Stellenbosch University (South Africa) we have added (somewhat) contrasting cases in each region, which showed a decline of democratic levels and qualities in recent years. In this way, we employ a "Most Similar" (in each region) "Different Outcomes" (MSDO) design. This allows to "control" for broader regional geopolitical, historical and cultural similarities and to focus the attention on the contrasts between the selected cases.

The selected pairwise and triple comparisons are the following:

- North America: United States (USA) and Canada (CAN);

- Europe: Germany (DEU) and Italy (ITA), Estonia (EST) and Poland (POL);

- Latin America: Argentina (ARG), Chile (CHL) and Uruguay (URY);

- East Asia: South Korea (KOR), Taiwan (TWN) and the Philippines (PHL);

- Sub-Saharan Africa: South Africa (ZAF) and Kenya (KEN).

The remaining democratic "benchmark" case of Sweden and the most drastic democratic decline in Turkey were also retained. This leaves us with 16 cases for the "cross-area" analysis.

The three leading research questions are:

1. Why is democracy in trouble globally?

2. Why do some democracies in the same region remain stable while others regress?

3. Which cross-area commonalities can be identified for the selected cases?

\section{Global Development of Liberal Democracy, 1990-2018}

As a first step, we looked at the development of "liberal democracy" globally and on a regional basis since the latest major "wave" [Huntington 1991] in the early 1990s. For this purpose, we use the "Varieties of Democracy" (V-Dem) data set $^{1}$. This is the most comprehensive and valid data set so far. Here we use the V-Dem "liberal democracy index", which is an

\footnotetext{
1 Varities of Democracy Dataset. URL: https://www.v-dem.net/_(accessed: 27.04.2020).
}

aggregated measure on a scale ranging between 1 and 0 . It also allows, as will be shown below, a dis-aggregation of the various components of liberal democracy as defined in the V-Dem project. These developments are shown in Fig. 3. The broad regional sub-division here follows the categorization as used by V-Dem.

The detailed values are presented in Table 3 .

Table 3

Liberal Democracy Index 1990 — 2018, by region

\begin{tabular}{|l|c|c|c|}
\hline Region & $\mathbf{1 9 9 0}$ & $\mathbf{2 0 0 7}$ & $\mathbf{2 0 1 8}$ \\
\hline East Asia & 0.29 & 0.46 & 0.44 \\
\hline $\begin{array}{l}\text { Eastern Europe and } \\
\text { Central Asia }\end{array}$ & 0.28 & 0.45 & 0.4 \\
\hline European Union & 0.66 & 0.78 & 0.71 \\
\hline Latin America & 0.41 & 0.5 & 0.46 \\
\hline $\begin{array}{l}\text { Middle East \& North } \\
\text { Africa }\end{array}$ & 0.15 & 0.18 & 0.19 \\
\hline North America & 0.6 & 0.69 & 0.68 \\
\hline Sub-Saharan Africa & 0.16 & 0.31 & 0.31 \\
\hline World & 0.31 & 0.41 & 0.4 \\
\hline
\end{tabular}

Source: calculated by the author.

As can be seen, during the last three decades there has been a strong increase in the beginning with a peak in the mid-2000s, i.e. before the Great Recession. The subsequent decline has been relatively weak. It was strongest in the EU, post-communist Europe and Latin America. The other regions remained stable, albeit at very low levels in Sub-Saharan Africa and the MENA region. This already indicates that region-specific factors have to be considered in addition to global trends.

The intra-regional comparisons are done by respective regional and country experts in the TRU project. Here, we focus on the cross-area aspects of the selected cases employing crisp-set and fuzzy-set QCA as briefly outlined above.

\section{The State of Democracy - Cross-area Analysis}

Here, we first use crisp-set QCA (with dichotomized conditions and outcome) to test some major hypotheses of empirical democratic theory [Berg-Schlosser 2007; Coppedge 2012] with V-Dem version 9 data $^{2}$ [Coppedge et al.

2 Varities of Democracy Dataset. Version 9. URL: https:/www.v-dem.net/en/data/archive/previous-data/dataversion-9/ (accessed: 27.04.2020). 


\section{Liberal Democracy Index}

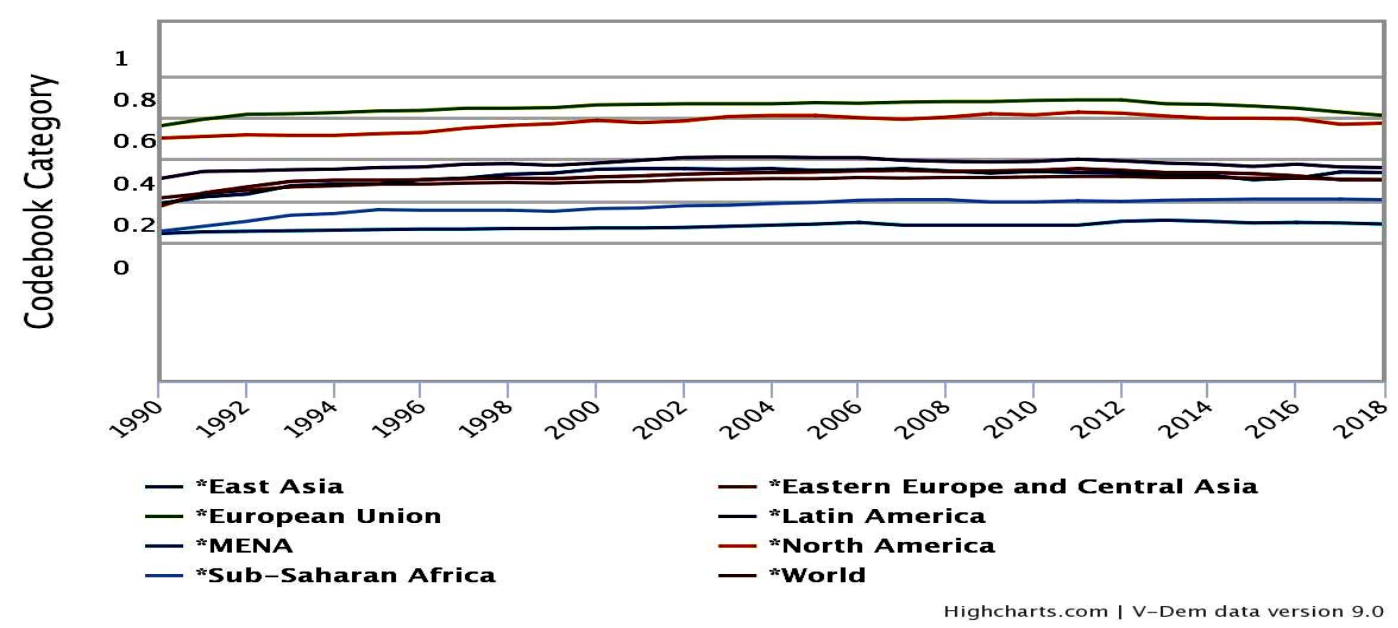

Fig. 3. Global development of liberal democracy, by region Source: designed by the author.

2019]. We first test some factors influencing the level of democracy using the "liberal democracy" index. This is composed of the "polyarchy" index and the "liberal component index". The former consists of five components of the "electoral principle" of democracy: "This is presumed to be achieved when suffrage is extensive; political and civil society organizations can operate freely; elections are clean and not marred by fraud or systematic irregularities; and the chief executive of a country is selected directly or indirectly through elections" [Coppedge et al. 2019: 41]. The latter includes the rule of law and the judicial and legislative constraints on the executive [Coppedge et al. 2019: 45]. These eight components are aggregated into a single scale ranging from 0 to 1 [Coppedge et al. 2020]. For the dichotomized outcome of crisp-set QCA we use a threshold of 0.7 on the "libdem 2018" variable. For this and the other thresholds below we use the "tresholdsetter" in TOSMANA 3 , which visualizes the actual distribution of cases of each indicator. Standard statistical measures such as the mean or median are often not good thresholds. The six cases below the libdem threshold are indicated in the truth table 4 below (outcome 0).

Tool for Small-N Analysis (QCA). https://www.tosmana.net/ (accessed: 27.04.2020).
Our first test concerns the well-known "Lipset hypothesis" [Lipset 1959; Przeworski, Alvarez, Cheibub, Limongi 2000] of the effects of higher socio-economic development on democratic stability. This we measure here by values of the "Human Development Index" (HDI 2017) and two of its sub-dimensions, level of income measured by "purchasing power parities" (Income2017) and level of education (Education2017) with thresholds of 0.8 each for high or low conditions on the standardized scales from 0 to $1^{4}$. In the terminology of Boolean algebra, this situation can be summarized in a QCA "truth table" listing the values of the conditions of our 16 cases with regard to the respective outcome. Where identical conditions lead to a different outcome this is marked as a contradiction (C). The truth table looks as follows (see Table 4).

Here we can see that most of our cases correspond to the "Lipset" hypothesis both in a positive and a negative sense: The less developed countries have a lower level of "liberal democracy", the highly developed ones have a higher score. A few cases have a mixed pattern, only Poland among the highly developed ones leads to a contradictory outcome (the outcome

${ }^{4}$ Global Human Development Indicators // United Nations Development Programme (UNDP). 2020. URL: http://hdr.undp.org/en/countries (accessed: 08.03.2020). 
for the contradictory cases is indicated in the parentheses).

Truth Table Socio-economic Development and Liberal Democracy

\begin{tabular}{|c|c|c|c|c|}
\hline Country & $\frac{\sqrt{0}}{\hat{\sigma}}$ & 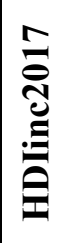 & 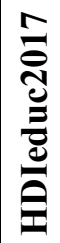 & 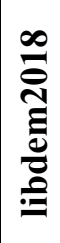 \\
\hline KEN, PHL, ZAF & 0 & 0 & 0 & 0 \\
\hline TUR & 0 & 1 & 1 & 0 \\
\hline ARG & 1 & 0 & 1 & 0 \\
\hline ITA, TWN, URY & 1 & 1 & 0 & 1 \\
\hline $\begin{array}{l}\text { CAN (1), CHL (1), DEU (1), } \\
\text { EST (1), KOR (1), POL (0), } \\
\text { SWE (1), USA(1) }\end{array}$ & 1 & 1 & 1 & $\mathrm{C}$ \\
\hline
\end{tabular}

Source: calculated by the author.

The algorithm in the QCA software (here we use TOSMANA, version 1.61) can now reduce this complexity as much as possible to some "most parsimonious" results (including socalled "logical remainder cases", R). These "logical remainders" represent possible combinations of conditions that are not covered by our empirical cases. In some instances, this can be used for further reduction by employing "simplifying assumptions", i.e. the constellations of these "logical remainders". For reasons of space and simplicity, the details of these simplifying assumptions for each procedure are not reported below.

For the outcome low level of democracy (0) we obtain the formula:

0R: $\quad$ hdi2017 + hdiinc2017

(KEN, PHL, ZAF, TUR) (ARG, KEN, PHL, ZAF)

Lower case letters in crisp-set QCA indicate low values of conditions; the + symbol stands for OR in Boolean algebra, the ${ }^{*}$ symbol stands for AND.

Thus, the above formula can be read as follows: Either a low Human Development Index is the main condition for the low level of democracy in Kenya, the Philippines, South Africa and Turkey OR a low level of income as in Argentina, Kenya, the Philippines and South Africa can account for this.

For the high level of democracy outcome (1) the formula is:

$$
\begin{aligned}
& \text { 1R: HDIINC2017* hdieduc2017 } \\
& \text { (ITA, TWN, URY) }
\end{aligned}
$$

This means that a high level of income AND a somewhat lower level of education are the combined conditions for this outcome in Italy, Taiwan and Uruguay. The contradictory cases (outcome C) are not included in these formulas.

If we include the contradiction (C) here, we get the following result for the positive outcomes:

\section{RC:}

$$
\text { HDI2017 * HDIINC2017 }
$$

(CAN, CHL, DEU, EST, KOR, POL, SWE, USA, ITA, TWN, URY)

Thus, all positive outcomes can be explained by a combination of a high HDI AND a high income (Poland, as indicated in the truth table, is the exception here). This means that in order to eliminate this contradiction we have to look for additional or alternative conditions.

The state of democracy in our cases is also related to their actual governmental processes and performance. The World Bank "good governance" data are the only ones which cover this aspect more fully. In addition to the "voice and accountability" and "rule of law" dimensions, which, taken together, can also be interpreted as measures of liberal democracy [Berg-Schlosser 2007], these comprise four other indices: "government effectiveness" (i.e. the quality of the bureaucracy and public services), the "regulatory burden" (i.e. market-unfriendly policies like price and trade controls), "graft" (i.e. the exercise of public power for private gain) including various forms of corruption, nepotism or clientelism, and "political stability" or its opposite, the extent of social unrest and violence. All indicators have a range of -2.5 to +2.5 , for our purposes here we set the threshold at $0^{5}$.

5 Worlwide Governance Indicators. URL: 27.04.2020). 
Truth Table Good Governance and Liberal Democracy

\begin{tabular}{|c|c|c|c|c|c|}
\hline Country & $\begin{array}{l}\infty \\
\bar{\pi} \\
\frac{\pi}{\pi} \\
\frac{\pi}{2} \\
\vdots\end{array}$ & 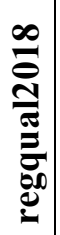 & 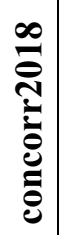 & 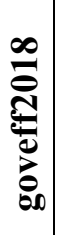 & 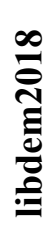 \\
\hline KEN & 0 & 0 & 0 & 0 & 0 \\
\hline ARG, TUR & 0 & 0 & 0 & 1 & 0 \\
\hline ZAF & 0 & 1 & 0 & 1 & 0 \\
\hline POL & 0 & 1 & 1 & 1 & 0 \\
\hline PHL & 1 & 1 & 0 & 1 & 0 \\
\hline $\begin{array}{l}\text { CAN, CHL, DEU, EST, ITA, } \\
\text { KOR, SWE, TWN, URY, USA }\end{array}$ & 1 & 1 & 1 & 1 & 1 \\
\hline
\end{tabular}

Source: calculated by the author.

\section{Result: 0R}

$$
\begin{gathered}
\text { polstab2018 } \\
(\mathrm{ARG}, \mathrm{TUR}, \mathrm{KEN}, \mathrm{POL}, \mathrm{ZAF}) \\
\text { (ARG, TUR, KEN, }
\end{gathered}
$$
PHL, ZAF)

Here, we get a much better result without any contradictory constellations. The formula shows that either a low level of political stability as in Argentina, Turkey, Kenya, Poland and South Africa OR a weak control of corruption as in Argentina, Turkey, Kenya, the Philippines and South Africa are the main conditions affecting low liberal democracy. This example also shows that some of the same countries fulfill both conditions.

\section{Result: 1R}

$$
\text { POLSTAB2018* CONCORR2018 }
$$

(CAN, CHL, DEU, EST, ITA, KOR, SWE, TWN, URY, USA)

Again we see a clear-cut pattern: all strong democracies have high political stability AND strong control of corruption.

In the TRU project a number of other hypotheses are tested as well. Here, for illustrative purposes, we just present the two mentioned.

As a further more refined procedure, we employed fuzzy-set $Q C A$, which retains the full information of interval scales for both conditions and the outcome. For this purpose, we calibrated the scales concerning their most meaningful range. For fuzzy sets you also have to set a minimum level of consistency, which we put here at 0.95 (lower consistency showing more contradictions).

The truth table of the socio-economic conditions for liberal democracy now looks as follows (see Table 6a).

Table $6 a$

\begin{tabular}{|c|c|c|c|c|}
\hline Country & $\frac{\sqrt{0}}{\hat{0}}$ & 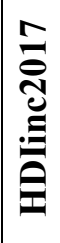 & 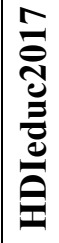 & 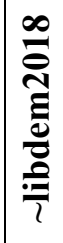 \\
\hline KEN, PHL (Cons: 1,0000) & 0 & 0 & 0 & 1 \\
\hline ZAF (Cons: 1,0000 ) & 0 & 1 & 1 & 1 \\
\hline TWN (Cons: 0,9749) & 1 & 1 & 0 & 1 \\
\hline $\begin{array}{l}\text { ARG, CAN, CHL, DEU, EST, ITA, } \\
\text { KOR, POL, SWE, TUR, URY, USA } \\
\text { (Cons: } 0,6195 \text { ) }\end{array}$ & 1 & 1 & 1 & 0 \\
\hline
\end{tabular}

Truth Table Socio-economic Conditions, Fuzzy Sets, Negative Outcome

Source: calculated by the author.

The $\sim$ symbol (tilde) here indicates the negative ("negated") outcome. The software produced the following result:

Result (0R):
\begin{tabular}{|c|c|c|}
\hline \hline & Consistency & Coverage \\
\hline \hline HDI2017 + HDIEDUC2017 & 0,9734 & 0,6753 \\
\hline \hline
\end{tabular}

This means that either a low HDI OR a low level of education is responsible for weak democracy with a very high level of consistency and coverage of 0.67 (\% of cases included in the solution). There usually is a trade-off between levels of consistency and coverage. As the truth table shows, Poland and Turkey with a high level of socio-economic development are included here with the strong democracies, i.e. as contradictions. In contrast to crisp-set QCA, in fuzzy-set QCA the truth tables for the negative and positive outcomes can be different. Therefore, we show both versions here. For the positive outcomes we had to set the consistency level relatively low at 0.75 to get a more meaningful result. The truth table now looks like this (see Table 6b): 
Table $6 b$

Truth Table Socio-economic Conditions, Fuzzy Sets, Positive Outcome

\begin{tabular}{|c|c|c|c|c|}
\hline Country & 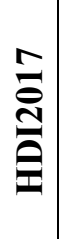 & 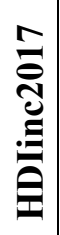 & 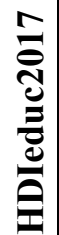 & 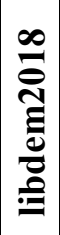 \\
\hline KEN, PHL (Cons: 0,7111) & 0 & 0 & 0 & 0 \\
\hline ZAF (Cons: 0,8221$)$ & 0 & 1 & 1 & 1 \\
\hline TWN (Cons: 0,8717 ) & 1 & 1 & 0 & 1 \\
\hline $\begin{array}{l}\text { ARG, CAN, CHL, DEU, EST, ITA, } \\
\text { KOR, POL, SWE, TUR, URY, USA } \\
\text { (Cons: } 0,7580)\end{array}$ & 1 & 1 & 1 & 1 \\
\hline
\end{tabular}

Source: calculated by the author.

\section{Result 1R:}

\begin{tabular}{|c|c|c|}
\hline & Consistency & Coverage \\
\hline \hline HDIINC2017 & 0,6942 & 0,9833 \\
\hline
\end{tabular}

I.e. a high HDI with a relatively low consistency (i.e. including the contradictory cases of Poland and Turkey), but a very high coverage explains the positive outcome. "Logical remainder cases" and some "simplifying assumptions" were used each time. This again confirms the broad "Lipset" hypothesis now with more differentiated data, but also shows some of the remaining contradictions (with Poland and Turkey included among the stronger democracies).

We also again tested the four World Bank Governance indicators with fuzzy set QCA. The truth table for the negative outcome looks like this (for reasons of space, we do not report the truth table for the positive outcome here) (see Table 7).

This shows that the weaker democracies have a rather mixed pattern for these indicators, whereas the large group of stronger democracies scores high on all of them. The most parsimonious result for the negative outcome (weak democracy, consistency threshold 0.9) is the following:

Result 0R:

\begin{tabular}{|c|c|c|}
\hline \hline & Consistency & Coverage \\
\hline \hline CORR2018 + STAB2018 & 0,9481 & 0,8783 \\
\hline
\end{tabular}

Truth Table "Good Governance", Fuzzy Sets, Negative Outcome

\begin{tabular}{|c|c|c|c|c|c|}
\hline Country & 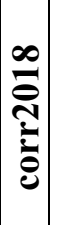 & $\begin{array}{l}\infty \\
\frac{\infty}{\delta} \\
\frac{\tilde{J}}{\tilde{T}} \\
\frac{\pi}{n}\end{array}$ & 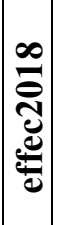 & 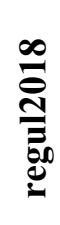 & 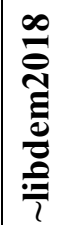 \\
\hline KEN (Cons: 0,9991) & 0 & 0 & 0 & 0 & 1 \\
\hline TUR (Cons: 0,9991) & 0 & 0 & 1 & 0 & 1 \\
\hline ZAF (Cons: 0,9775) & 0 & 0 & 1 & 1 & 1 \\
\hline ARG (Cons: 0,9990) & 0 & 1 & 1 & 0 & 1 \\
\hline PHL (Cons: 0,9708 ) & 0 & 1 & 1 & 1 & 1 \\
\hline POL (Cons: 0,9428 ) & 1 & 0 & 1 & 1 & 1 \\
\hline $\begin{array}{l}\text { CAN, CHL, DEU, EST, ITA, } \\
\text { KOR, SWE, TWN, URY, USA } \\
\text { (Cons: } 0,6901)\end{array}$ & 1 & 1 & 1 & 1 & 0 \\
\hline
\end{tabular}

Source: calculated by the author.

This means that either a low level of political stability OR a low level of the control of corruption are responsible for weak democracy with a very high level of consistency and a coverage of almost 0.9 (according to fs-QCA conventions the $\sim$ symbol is used here again for the negative versions, upper-case lower-case letters as in crisp-set QCA can only be used for dichotomized conditions).

The positive outcome (consistency threshold 0.86 ) is indicated by

Result 1R:

\begin{tabular}{|c|c|c|}
\hline \hline & Consistency & Coverage \\
\hline \hline CORR2018 * STAB2018 & 0,8870 & 0,9521 \\
\hline
\end{tabular}

I.e. a high level of political stability OR a high level of control of corruption with a high consistency and a very high coverage (for reasons of space the separate truth table with the consistency values for each case is not reported here). This again shows that the "governance" conditions produce better results for liberal democracy than the merely socio-economic ones.

\section{Conclusions}

This article presented an overview of some important recent developments in comparative area studies. It first discussed some of the 
broader epistemological foundations of the social sciences and the specific restrictions with regard to "medium-range theorizing" and the possibility of "morphothetic" findings in cross-area research. It then pointed to some recent methodological innovations in this respect, which are more suitable in small or medium $\mathrm{N}$ situations than more general statistical procedures.

This was followed by an example from an ongoing large international research project concerned with global and regional developments of democracy over the last three decades, which can illustrate this approach. The analysis presented here was confined to two major aspects of empirical democratic theory, the impact of socio-economic developments and "modernization" (the "Lipset hypothesis") and the consequences of "good" (or bad!) governance for democracy using crisp-set and fuzzy-set QCA. It could be shown that the Lipset hypothesis was confirmed for a larger group of countries across regions, albeit with some remaining contradictory cases. The governance analysis was more conclusive, in particular as far as high levels of political stability and a strong control of corruption for the successful democracies in our study are concerned, the opposite was true for the deteriorating cases.

In the TRU project mentioned, the scope of analysis is actually much larger. There, not only the level of liberal democracy, but also the extent of backsliding during the last decade and its major causes are analyzed. This is done both with specific regional case-based comparisons and on a cross-area basis. In addition to these studies at the macro- (country-) level, microlevel analyses are conducted using the latest waves of the "World Values Surveys" (WVS) and "European Values Surveys" (EVS) ${ }^{7}$ looking at the actual attitudes and perceptions of the general populations with regard to the support (or not) of democracy and similar attitudes like social trust etc. and their changes over time. This then leads to an assessment at the meso-level (on the right-hand side of Figure 1 above) of the consequences of such developments like protest movements, populist parties, declining party institutionalization and similar recent phenomena. Finally, some conclusions will be drawn as to the future of democracy and/or authoritarian regimes in the international constellation of today's world. But this remains to be seen...

6 World Values Survey Database. $\begin{array}{r}\text { URL: } \\ \text { http://www.worldvaluessurvey.org/wvs.jsp }\end{array}$
$\begin{aligned} & \text { 27.04.2020). } \\ & 7\end{aligned} \quad$ European $\quad$ Values $\quad$ Survey.
https://europeanvaluesstudy.eu/ (accessed: 27.04 .2020$).$

Received / Поступила в редакцию: 28.04.2020

Accepted / Принята к публикации: 18.05.2020

\section{References / Библиографический список}

Aarebrot, F.H. \& Bakka, P.H. (2006). Die vergleichende Methode in der Politikwissenschaft. In: Berg-Schlosser, D. \& Müller-Rommel, F. (Eds.). Vergleichende Politikwissenschaft. 4th. ed., Wiesbaden: VS Verlag. P. 57 -76.

Ahram, A.I. (2009). The Theory and Method of Comparative Area Studies. IPSA Committee on Concepts and Methods, Working Paper Series.

Ahram, A.I., Köllner, P. \& Sil, R. (Eds.). (2018). Comparative Area Studies: Methodological Rationales and CrossRegional Applications. New York: Oxford University Press. DOI:10.1093/oso/9780190846374.001.0001

Almond, G.A. \& Genco, S. (1977). Clouds, Clocks, and the Study of Politics. World Politics, 29 (04), 489-522. DOI: $10.2307 / 2010037$

Almond, G.A. (2002). Ventures in Political Science. Boulder: Lynne Rienner.

Badie, B., Berg-Schlosser, D. \& Morlino, L. (2011). (Eds.) International Encyclopedia of Political Science. Los Angeles: SAGE.

Basedau, M. \& Köllner, P. (2007). Area Studies, Comparative Area Studies, and the Study of Politics: Context, Substance, and Methodological Challenges. Zeitschrift für Vergleichende Politikwissenschaft, 1 (01), 105124. DOI: $10.1007 / \mathrm{s} 12286-007-0009-3$

Bates, R., Greif, A., Levi, M., Rosenthal, J.-L. \& Weingast, B.R. (1998). Analytic Narratives. Princeton: Princeton University Press. 
Berger, P.L. \& Luckmann, T. (1969). Die gesellschaftliche Konstruktion der Wirklichkeit. Frankfurt am Main: Fischer.

Berg-Schlosser, D. \& Quenter, S. (1996). Makro-quantitative vs. akro-qualitative Methoden in der Politikwissenschaft - Vorzüge und Mängel komparativer Verfahrensweisen am Beispiel der Sozialstaatstheorie. Politische Vierteljahresschrift, 37 (01), 100-118.

Berg-Schlosser, D. (1985). Leistungen und Fehlleistungen politischer Systeme der Dritten Welt als Kriterium der Entwicklungspolitik. Zeitschrift für Konjunkturpolitik, 31, 79-114.

Berg-Schlosser, D. (1990). Third World Political Systems - Classification and Evaluation 1960-1980. In: Bebler, A. \& Seroka, J. (Eds.). Contemporary Political Systems. Boulder: Lynne Rienner Publishers. P. 173201.

Berg-Schlosser, D. (2008a). Neighbourhood Effects of Democratization in Europe. Taiwan Journal of Democracy, 4 (02), 29 - 45. DOI: 10.29654/TJD.200812.0002

Berg-Schlosser, D. (2008b). Determinants of Democratic Successes and Failures in Africa. European Journal of Political Research, 47 (03), 269-306. DOI: 10.1111/j.1475-6765.2007.00768.x

Berg-Schlosser, D. (2012). Mixed Methods in Comparative Politics. London: Palgrave.

Berg-Schlosser, D. (Eds.). (2007). Democratization - The State of the Art. Opladen \& Farmington Hills: Barbara Budrich Publishers.

Cohen, M.R. \& Nagel, E. (1934). An Introduction to Logic and Scientific Method. New York: Harcourt, Brace \& World.

Coleman, J.S. (1990). Foundations of Social Theory. Cambridge: Belknap Press.

Coppedge, M. (2012). Democratization and Research Methods. Cambridge: Cambridge University Press. DOI: $10.1017 /$ CBO9781139016179

Coppedge, M. et al. (2019). V-Dem Codebook v9. Varieties of Democracy (V-Dem) Project.

Coppedge, M. et al. (2020). Varieties of Democracy. Measuring Two Centuries of Political Change. Cambridge: Cambridge University Press. DOI: 10.1017/9781108347860

De Meur, G. \& Berg-Schlosser, D. (1994). Comparing Political Systems. Establishing Similarities and Dissimilarities. European Journal of Political Research, 26 (02), 193-219. DOI: 10.1111/j.14756765.1994.tb00440.x

De Meur, G. \& Berg-Schlosser, D. (1996). Conditions of Authoritarianism, Fascism and Democracy in Inter-war Europe: Systematic Matching and Contrasting of Cases for 'Small n' Analysis. Comparative Political Studies, 29 (04), 423-468. DOI: 10.1177/0010414096029004003

Elster, J. (1989). Nuts and Bolts for the Social Sciences. Cambridge: Cambridge University Press.

Esser, H. (1993). Soziologie. Allgemeine Grundlagen. Frankfurt am Main, New York: Campus.

Geertz, C. (1973). The Interpretation of Cultures. New York: Basic Books.

Hegel, G.W.F. (1833/1956). Grundlinien der Philosophie des Rechts, Werke, Frankfurt am Main.

Hempel, C. (1952). Fundamentals of Concept Formation in Empirical Science. Chicago: University of Chicago Press.

Huntington, S.P. (1991). The Third Wave. Democratization in the Late Twentieth Century. Norman: University of Oklahoma Press.

Huntington, S.P. (1996). The Clash of Civilizations and the Remaking of World Order. New York: Simon \& Schuster.

Inglehart, R.F. (1997). Modernization and Postmodernization. Cultural, Economic, and Political Change in 43 Societies. Princeton: Princeton University Press.

Inglehart, R.F. (2018). Cultural Evolution: People's Motivations are Changing, and Reshaping the World. Cambridge: Cambridge University Press. DOI: 10.1017/9781108613880

Katzenstein, P. (2005). A World of Regions: Asia and Europe in the American Imperium. Ithaca: Cornell University Press.

Laitin, D. (2007). Culture, Rationality, and the Search for Discipline. In: Munck, G.L. \& Snyder, R. (Eds.). Passion, Craft, and Method in Comparative Politics. Baltimore: Johns Hopkins University Press. P. 601-648.

Lijphart, A. (1971). Comparative Politics and the Comparative Method. American Political Science Review, 65 (03), 682-693. DOI: $10.2307 / 1955513$

Lijphart, A. (1975). The Comparable-cases Strategy in Comparative Research. Comparative Political Studies, 8 (02), 158-177. DOI: $10.1177 \% 2$ F001041407500800203

Lipset, S.M. (1959). Some Social Requisites of Democracy: Economic Development and Political Legitimacy. American Political Science Review, 53 (01), 69-105. DOI: 10.2307/1951731

Luhmann, N. (1990). Die Wissenschaft der Gesellschaft. Frankfurt am Main: Suhrkamp. 
Lukács, G. (1967). Geschichte und Klassenbewusstsein. Darmstadt: Luchterhand.

Merton, R. (1949). Social Theory and Social Structure. Toward the Codification of Theory and Research. Glencoe: The Free Press.

Mill, J.S. (1843/1974). A System of Logic. London: Routledge \& Kegan Paul.

Moses, J.W. \& Knutsen, T.L. (2012). Ways of Knowing. Competing Methodologies in Social and Political Research. 2nd ed. London: Palgrave.

Niedermayer, O. \& Widmaier, U. (2006). Quantitativ vergleichende Methoden. In: Berg-Schlosser, D. \& MüllerRommel, F. (Eds.). Vergleichende Politikwissenschaft: ein einführendes Studienhandbuch. 4th ed. Opladen: Leske + Budrich. P. 103-120.

Popper, K.R. (1969). Logik der Forschung. 3rd ed. Tübingen: Mohr.

Popper, K.R. (1993). (Eds.). Objektive Erkenntnis. Ein evolutionärer Entwurf. 2nd ed. Hamburg.

Przeworski, A. \& Teune, H. (1970). The Logic of Comparative Social Inquiry. New York: Wiley.

Przeworski, A. (1987). Methods of Cross-national Research, 1970-1983. In: Dierkes, M., Weiler, H.N. \& Antal, A.B. (Eds.). Comparative Policy Research. Aldershot: Gower. P. 31- 49.

Przeworski, A., Alvarez, M., Cheibub, J.A. \& Limongi F. (2000). Democracy and Development. Cambridge: Cambridge University Press.

Ragin, C.C. (1987). The Comparative Method. Moving beyond Qualitative and Quantitative Strategies. Berkeley: University of California Press.

Ragin, C.C. (2000). Fuzzy-set Social Science. Chicago: University of Chicago Press.

Ragin, C.C. (2008). Redesigning Social Inquiry. Fuzzy Sets and Beyond. Chicago: University of Chicago Press.

Rihoux, B. \& Ragin, C.C. (Eds.). (2009). Configurational Comparative Methods: Qualitative Comparative Analysis (QCA) and Related Techniques. London: SAGE Publications.

Simon, H.A. (1957). Models of Man, Social and Rational: Mathematical Essays on Rational Human Behavior in a Social Setting. New York: Wiley.

Szanton, D.L. (Eds.). (2002). The Politics of Knowledge. Area Studies and the Disciplines. Berkeley: University of California Press.

Van Beek, U. (Eds.). (2005). Democracy under Construction: Patterns from Four Continents. Opladen: Barbara Budrich Publishers.

Weber, M. (1922). Wirtschaft und Gesellschaft. Tübingen: J.C.B. Mohr.

Windelband, W. (1912). Logik. Encyclopädie der philosophischen Wissenschaften. Vol. 1. Tübingen.

About the author: Berg-Schlosser Dirk — Professor Emeritus of Political Science, Philipps-Universität Marburg, Germany (e-mail: bergschl@staff.uni-marburg.de).

Сведения об авторе: Берг-Шлессер Дирк - заслуженный профессор политологии Марбургского университета им. Филиппа, Германия (e-mail: bergschl@staff.uni-marburg.de). 